\title{
FEDERAL PROCUREMENT AND EQUAL EMPLOYMENT OPPORTUNITY
}

\author{
N. THOMPSON POWERs*
}

Like private individuals and businesses, the Government enjoys the unrestricted power to produce its own supplies, to determine those with whom it will deal, and to fix the terms and conditions upon which it will make needed purchases.

-Perkins v. Lukens Steel Co., 210 U.S. I13, I27 (I940).

The power implicit in the vast procurement activities of the federal government has long been used by the Congress and the executive branch to correct or avoid dangerous, unjust, or otherwise undesirable conditions-political, social, or economic. As a result, by legislation or by presidential executive order, standards have been established calling for federal procurement contractors to observe certain prevailing wages, hours, and working conditions, ${ }^{1}$ use materials and supplies produced in the United States, ${ }^{2}$ favor the blind, ${ }^{3}$ avoid using child ${ }^{4}$ or convict labor, ${ }^{5}$ give attention to the needs of small business ${ }^{6}$ and firms in depressed areas ${ }^{7}$ and provide equal employment opportunity without regard to race, creed, color, or national origin. ${ }^{8}$

As might be expected, some of those involved in the purchase of the government's supplies and services have expressed dismay at this approach to procurement. ${ }^{0}$ However, it has also been noted that the size of federal procurement itself "creates social, economic and political situations," and that "the choice before the government is, in a sense, not whether it should burden its procurement processes

* A.B. I95r, Duke University; LL.B. I954, Harvard University. Special Counsel, President's Committec on Equal Employment Opportunity, Special Assistant to the Secretary of Iabor.

The author acknowledges the assistance of Roger F. Lewis in the preparation of this article.

The views expressed are those of the author and are not necessarily those of the President's Committee on Equal Employment Opportunity or of the Department of Labor.

${ }^{2}$ Walsh-Healey Act, 49 Stat. 2036 (1936), as amended, 4I U.S.C. \$\$35-42 (x958); Davis-Bacon Act, 46 Stat. I494 (I93I), as amended, 40 U.S.C. $\$ 276$ (a)(I)-276(a)(7) (1958), as amended, 40 U.S.C. $\$ 276$ (a) (Supp. III, I962); Eight Hour Law, 27 Stat. 340 (1892), as amended, 40 U.S.C. $\$ \$ 321-$ 326 (1958); Pub. L. No. 87-581, 87th Cong., 2d Sess. \$\$ I01-106 (1962).

${ }^{2}$ Buy American Act, 47 Stat. 1520 (1933), as amended, 63 Stat. I024 (1949), 4 I U.S.C. \$\$ roa-rod (I952). See also, Strategic and Critical Materials Stockpiling Act, 50 U.S.C. $\$ 98 \mathrm{~b}$ (a) (195r) and Department of Defense Appropriation Act, 196I $\$ 523,74$ Stat. 353 (1960).

${ }^{8} 52$ Stat. II96 (1938), 4I U.S.C. $\$ 46-48$ (I959).

- See e.g., Walsh-Healey Act, 49 Stat. 2036 (I936), as amended, 4r U.S.C. \$35(d) (I957).

Ibid. See also, 62 Stat. 703 (I948), I8 U.S.C. $\$ 436$ (1959), which applies only to the labor of federal prisoners; 32 C.F.R. $\$ \$$ 12.20I-.203 (rg6r); Exec. Order No. 325A (May 18, 1905).

${ }^{6}$ 70A Stat. I27 (1956), 10 U.S.C. 230 I (1959); 69 Stat. 580 (1955), 50 U.S.C. App. \$2151(d) (I959).

${ }^{7}$ See e.g., 32 C.F.R. $\$ \$$ 7.104-20 (I96I); Defense Manpower Policy No. 4, 32 C.F.R. 5283 (I964).

${ }^{8}$ Exec. Order No. I0925, 26 Fed. Reg. 1977 (I96I); Exec. Order No. IIII4, 28 Fed. Reg. 6485 (Ig63).

'See Van Cleve, The Use of Federal Procurement to Achieve National Goals, rg6r Wis. L. Rev. 566. 
with specific attention to social, economic and political goals. It is, instead, determining which social, economic and political purposes to pursue."10

Presidents have for more than twenty years determined to promote nondiscrimination in government contract work. ${ }^{11}$ Two executive orders are currently in effect on this subject. ${ }^{12}$ They were issued by the late President Jotn F. Kennedy and they apply to federal procurement generally and to federally-assisted construction contracts. These orders call for affirmative action to insure nondiscriminatory treatment in all aspects of employment, impose certain reporting obligations and sanctions for noncompliance and provide for efforts to promote labor union cooperation. Responsibility for coordination of the federal program under these orders was placed in a Committee on Equal Employment Opportunity under the chairmanship of then Vice President Lyndon B. Johnson.

Although much has been written about the legality of this line of executive orders, ${ }^{13}$ the courts have never been called upon to determine their enforceability. However, the courts have generally upheld the right of the executive branch to contract in such manner and on such terms as it considers appropriate to its constitutional and statutory responsibilities, except insofar as Congress has required or limited certain types of contracts or provisions therein. ${ }^{14}$ The legal situation was perhaps best summed up by the Comptroller General in commenting on Executive Order rog25:

So far as we are aware the propriety of clauses of the type under consideration has never been seriously questioned by any responsible administrative or judicial tribunal; nor has Congress seen fit to proscribe the use of such clauses by appropriate legislation. ${ }^{15}$

${ }^{10} \mathrm{Id}$. at 568 .

${ }^{11}$ In $194 \mathrm{I}$, President Roosevelt issued an executive order calling for nondiscrimination in employment in defense industries. Exec. Order No. 8802, 6 Fed. Reg. 3 rog (I94I). He subsequently extended this policy to all contracting agencies of government, Exec. Order No. goor, 6 Fed. Reg. 6787 (194r); Exec. Order No. 9346, 8 Fed. Reg. 7 I83 (I943), and made it clear that this policy was mandatory. Letter to the Attorney General, 8 Fed. Reg. I5419 (x943). Succeeding Presidents also issued executive orders reaffirming this policy of nondiscrimination in government contract employment. President Truman, Exec. Order No. I0308, I6 Fed. Reg. 12303 (195I); President Eisenhower, Exec. Order No. I0557, I9 Fed. Reg. 5655 (1954).

${ }^{12}$ See supra note 8.

${ }^{10}$ See Speck, Enforcement of Nondiscrimination Requirements for Government Contract Work, 63 Conom. L. Rev. 243, 244-50 ( 1963$)$; Pasley, The Nondiscrimination Clause in Government Contracts, 43 VA. L. Rev. 837 (I957). "It may be and has been argued that under the fifth amendment to the Constitution, federal government action may not be taken in aid of racial discrimination, and that nondiscrimination in government contract employment is a fact constitutionally required. See in this connection, Report to the White House, by the Leadership Conference on Civil Rights, August 29, I96r. Note also, Bolling v. Sharpe, 347 U.S. 497 (1954)." Birnbaum, Equal Employment Opportunity and Executive Order Iog25, II Kan. L. Rev. I7 n.2 (I962). To the same effect, see Todd v. Joint Apprenticeship Committee, Civil No. 63 C 1739, N.D., Ill., Nov. 8, r963.

14 See e.g., Kern-Limerick, Inc. v. Scurlock, 347 U.S. Iro, II6 (I954); Muschany v. United States, 324 U.S. 49,63 (I945); Jessup v. United States, 106 U.S. I47, I5I-52 (I882); United States v. Hodson, 77 U.S. (ro Wall.) 395, 406-08 (1870); United States v. Linn, 40 U.S. (I5 Peters) 290, 315-I6 (I84I); United States v. Tingey, 30 U.S. (5 Peters) II5, I27 (I83I).

${ }^{15} 40$ Decs. CoMp. GeN. 592 (rg6r). Furthermore, the Comptroller General has stated that Executive Order rog25 does not improperly restrict competition. Ibid. 
The coverage of the present executive orders, the obligations they impose and the procedures for enforcing them will be discussed in this article. However, since readers of this journal are interested in "contemporary problems" as well as in "law," it seems appropriate to discuss the reasons the executive branch has issued increasingly comprehensive standards for promoting equal employment opportunity in government contract work.

President Johnson eloquently stated the challenge that discrimination presents to our national ideals when he said:

While we in America have freed the slave of his chains, we have not freed his heirs of their color. Until justice is blind to color, until education is unaware of race, until opportunity ceases to squint its eyes at pigmentation of human complexion, emancipation will be a proclamation, but it will not be a fact. ${ }^{16}$

Eliminating discrimination in employment based on race, religion, or nationality is one of the principal objectives of civil rights leaders who see employment as the vital link between educational rights and political and social equality. Secretary of Labor W. Willard Wirtz who is also Vice-Chairman of the President's Committee on Equal Employment Opportunity, recognized this when he said:

The larger edifice of civil rights is itself dependent upon equality of employment opportunity. Without it, equality of citizenship is only an empty phrase. It is not enough for a man to be free to worship as he will, to enjoy freedom of speech, to be free of racial penalties in the exercise of suffrage, if he is not equally free to secure and hold a job. ${ }^{17}$

Discrimination in employment is not only unjust, it involves substantial economic waste as well. Part of the rationale for the first executive order prohibiting nondiscrimination by government contractors was that a nation at war needed the services of all who were qualified. ${ }^{18}$ While the war has since cooled, the national need is no less great.

Our country seeks an ever-growing economy and a continually rising standard of living-not only for our national strength but for our individual enjoyment as well. However, among the most significant barriers to these goals is continued inequality in opportunity for employment, education, and training-inequalities based not on competence or potential but based instead on race, creed, color, or national origin. The Council of Economic Advisers has estimated that we are losing \$17 billion a year in our gross national product because of racial discrimination alone. ${ }^{10}$

The individual cost of such discrimination is appalling. It is reflected in these statements:

\footnotetext{
${ }^{16}$ Remarks of then Vice President Johnson, Wayne State University, Detroit, Michigan, January 6, 1963.

${ }^{27}$ Address of Secretary Wirtz at the Michigan Celebration of the Iooth Anniversary of the Emancipation Proclamation, Detroit, Mich., June $30,1963$.

${ }^{18}$ Exec. Order No. 8802, 6 Fed. Reg. 3109 (I94I).

${ }^{20}$ Council of Economic Advisers, Cost of Racial Discrimination, Sept. 25, 1962.
} 
The unemployment rate of Negro workers is more than twice as high as that of the working force as a whole. ${ }^{20}$

Even when the Negro is employed, it is a significantly different kind of employment from what the white worker finds available. In I962, seventeen per cent of the employed nonwhites had white collar jobs; the corresponding proportion among whites was fortyseven per cent. ... On the other hand, fourteen per cent of all employed nonwhites are unskilled laborers in nonagricultural industries; the corresponding proportion among whites is only four per cent. ${ }^{21}$

A white worker with an eighth-grade education can expect to make more money during his lifetime than a Negro college graduate. ${ }^{22}$

The bars that have been erected against men because of their race, their creed and their color have not been bars against jobs solely. Even more importantly they have been bars against the opportunity to qualify for the jobs. ${ }^{23}$

L.

... about one-third of the three million adults in this country who cannot read or write are nonwhites . . . twenty-five per cent (or 2.3 million) of the nonwhites 25 years of age or older did not complete five years of schooling (compared with seven per cent of the adult white population). . . . almost half of the adult nonwhites in the country today did not finish grade school (compared with about twenty per cent of the whites). ${ }^{24}$

The average life expectancy of a white male American is sixty-eight years. The average life expectancy of a nonwhite male American is sixty-two. ${ }^{25}$

Contrary to popular assumptions time alone is not correcting these problems and will not do so. ${ }^{28}$ The nonwhite unemployment rate which was sixty per cent higher than the white rate in 1947-r949 has been more than twice as high as the white rate in each of the years $1954-1962 .^{27}$ The income of nonwhite workers as a percentage of income of white workers has declined from 56.8 per cent in $195^{28}$ to 53.4 per cent in $1962 . .^{29}$

These statistics are tangible evidence of economic trends now jeopardizing gains won for Negroes in production jobs in the I940's and early I950's. These trends make more imperative the need to remove discrimination in skilled trades and in

\footnotetext{
${ }^{20}$ President John F. Kennedy, Message to Congress on Civil Rights and Job Opportunities, June $\mathbf{9}$, I963, ro9 Cong. REc. I0552 (I963).

${ }_{31}$ Testimony of Secretary Wirtz before House Committee on the Judiciary, Subcommittee No. 5 on the President's Civil Rights Act of 1963 , June 27, 1963.

${ }_{22}$ Bureau of Census projection reported in S. REP. No. 867, 88th Cong., 2d Sess. 2 (Ig63).

${ }^{23}$ Remarks of then Vice-President Lyndon B. Johnson at the Equal Employment Opportunity Conference, St. Louis, Missouri, June 25, 1963.

${ }^{34}$ Secretary Wirtz, supra note 21.

${ }^{20}$ U.S. Dep't of Health, Education and Welfare, Vital Statistics of the United States, vol. II, sec. 2, table 2-2 (I96I).

${ }^{30}$ See Feild, $A$ New Look at Employment, 42 N.C.L. REv. 154 (1963).

${ }^{37}$ Secretary Wirtz, supra note 21 . The total unemployment situation of Negroes is even worse than appears from these figures. In 1952 among males aged $25-64,4.5$ per cent of whites and 5.4 per cent of nonwhites were not even seeking work. In $I 963$ the percentage had increased to 8.2 per cent for nonwhites but only to 4.9 per cents for whites. U.S. Dep'T of LABor, Report on Manpower ReQuirements, Resources Utilization and Training io3 (I964).

${ }^{38}$ U.S. Bureau of Labor Stattstics, Spectal Labor Force Report No. 33, table 8 (ig63).

${ }^{20}$ U.S. Bureau of Census, Current Population Reports ser. P-6o, No. 41 (Ig63).
} 
white collar work. As stated by Hobart Taylor, Jr., Executive Vice Chairman of the President's Committee on Equal Employment Opportunity:

In general, the rapid technological changes which have taken place in the past few years have been responsible for increased unemployment, particularly among the unskilled and the semi-skilled classes of workers. At the same time, the demand for skilled craftsmen has been substantially enhanced and, it is estimated, will continue on an upward curve. This shift in the composition of the labor force has created problems of particular severity for those minority groups which have been traditionally confined to unskilled employment and which have likewise suffered from inferior educational opportunity. ${ }^{30}$

John Feild, former Executive Director of the President's Committee, has also called attention to the growth experienced and anticipated in such white collar jobs as sales, clerical, and service-occupations in which Negroes have been underrepresented in the past. ${ }^{31}$

The problem of the minority group worker in the skilled trades and white collar work is not confined to one section of the country, to particular industries, or to one minority group. It exists in the North and West as well as in the South, in manufacturing as well as in construction, for American Indians, Puerto Ricans, and Mexican Americans, as well as for Negroes.

The trends in automation, technological change, and economic development that have produced the shifts in our occupational structure continue. The ability of our economy to provide jobs to all who are able and willing to work will continue to be challenged in the years ahead by ever increasing numbers of young people entering the work force, by those presently unemployed, and by those who will be displaced by technological change.

Executive orders prohibiting discrimination in government contract work ob. viously cannot provide a complete answer to such situations-however affirmative the action required of government contractors. What is needed are programs to increase economic growth, to combat poverty, to facilitate adjustments to technological change, to foster better education and training programs and to eliminate discrimination in employment based on race, religion, or nationality. The executive orders promoting equal employment opportunity on government contract work and on federally-assisted construction projects as well as in the federal service should be viewed as part of those programs as well as part of the effort to achieve civil rights for all.

\section{CONTRACTORS COVEREd}

Executive Order rog25 directs federal agencies to require those who contract with the federal government to agree to provide equal employment opportunity ${ }^{82}$ Executive Order IIII4 extends that requirement to those who contract for con-

${ }^{30}$ Taylor, The President's Committee on Equal Employment Opportunity, I6 Sw. L.J. I01 (xg62).

${ }^{81}$ Feild, supra note 26 , at 156 .

32 The effect of failure to include the equal employment opportunity clauses in government contracts is discussed in Speck, supre note 13, at 256-57. Executive Order rog25 also directs federal agencies to provide equal opportunity in their own employment. 
struction that is federally-assisted by federal grants, loans, insurance, or other financial assistance. It is estimated that 38,000 contractors are covered by Executive Order rog25 alone. However, all agreements entered into by the United States Government are not covered by this program. Nor are all federally-assisted construction projects subject to it. The purpose of this section is to explore the limits of coverage in each case.

\section{A. Contractual Relationship}

In the first place, the Comptroller General has pointed out that executive orders have limited applicability to agencies which are not in the executive branch. ${ }^{33}$ Accordingly, some agencies of the federal government so situated may not be required to include the equal employment opportunity clauses of Executive Order Iog25 in their contracts.

Similarly it may be determined that a particular statute authorizing a program involving federal financial assistance for construction has been written by Congress in such a way that the executive branch agency administering the program has no discretion to refuse such assistance to an applicant who meets the criteria for qualification contained in the statute. For this reason, Executive Order IIII4 directs agencies administering federal programs involving assistance for construction to condition such assistance on the inclusion of the equal employment opportunity clauses only "insofar as it may be consistent with law."34

Moreover, while Executive Order IIII4 provides for inclusion of the clauses in contracts for construction which are federally assisted, it does not require that these same clauses be included in the agreements for such federal assistance. ${ }^{35}$ Also because these and other grant agreements with state and local governments have a special governmental and nonprocurement character Executive Order I0925 is not considered to cover them. ${ }^{36}$

As indicated earlier, the President's power to require equal opportunity provisions in government contracts is based in part on the right of the government as a purchaser to indicate the terms on which it will do business and the willingness of

${ }^{33} 40$ DeCs. COMP. GeN. 592 (Ig6I).

as Sec. IoI. One of the purposes of title VI of the Civil Rights Act now pending in the Congress is to provide express legislative authority for executive branch agencies to decline to make grants which will be used on a discriminatory basis. The courts have already indicated their readiness to require nondiscriminatory use of federal grants. Simkins v. Moses H. Cone Memorial Hospital, 323 F.2d 959 (4th Cir. 1963 ), cert. denied, 376 U.S. 938 ( 1964 ); Pryor v. Poirier, Civil No. W-2219, D. Kansas, Nov. 27, rg6r.

${ }^{35}$ Except that if the applicant for federal assistance performs the construction work with its own work force it will be subject to the clauses unless it is a governmental agency and is performing the construction with its own permanent work force. Furthermore, the question of who is the applicant for federal assistance can be quite complicated in the case of certain housing guarantee or insurance programs. There may be other parties involved than the federal agency, the state or local government applicant and the contractor, such as a private "developer" contracting with the state or locality and in turn contracting for construction. For this reason, section $102(c)$ of Executive Order IIII4 authorizes individual agencies administering federal grants for construction to designate "other program participants" to be covered by the equal employment opportunity requirements.

${ }^{30}$ See Birnbaum, supra note I3 $_{3}$ at $29,30 \mathrm{n} .38$. 
contractors to agree to such provisions. Therefore, the clause is not included in certain arrangements which result from the government's right to compel the contractor's service under a statute.

\section{B. Types of Contracts}

"Government contracts" in which the equal employment opportunity clauses must be inserted, are defined by the President's Committee on Equal Employment Opportunity to mean government contracts "for supplies or services . . . or for the use of government property."37 This does not include contracts for the government's use of property which do not involve the furnishing of services or supplies as well. ${ }^{38}$

The range of federally-assisted construction contracts which are required to include the equal employment opportunity clause has been broadly defined in Executive Order IIII4 and the Rules and Regulations of the President's Committee. ${ }^{30}$ "Federal assistance" covers "funds obtained from the federal government or borrowed on the credit of the federal government pursuant to any federal program involving a grant contract, loan insurance or guarantee." 40 "Construction" is defined to include "rehabilitation, alteration, conversion, extension, demolition or repair of buildings, highways or other changes or improvements to real property."11 (In general the coverage is co-extensive with that of the Davis-Bacon prevailing wage standards in federal and federally-assisted construction.) ${ }^{42}$ The term "contracts" under which such federally-assisted construction takes place has been interpreted to include not only agreements with a construction contractor but also some arrangements under which the agency receiving federal assistance performs the construction work itself. ${ }^{43}$

Certain classes of contracts have been exempted from coverage by the President's Committee under the authority contained in the executive orders. ${ }^{44}$ These exemptions are in two general categories: contracts not affecting appreciable amounts of employment in the United States and contracts for less than certain dollar

${ }^{87} 4$ I C.F.R. $\$ 60-1.2(h)(1964)$.

${ }^{88}$ See Speck, supra note I3, at 25I, 252.

${ }^{39}$ But see discussion in text stipra at note 34 .

${ }^{10} 4$ I C.F.R. $\$ 60-1.2(i)(1964)$.

${ }_{41}$ C.F.R. $\$ 60-1.2(v)(x 964)$. Some interesting questions are presented as to when is a contract for sale of a building which has been started or completed a "contract for construction" within the meaning of Executive Order IIII4. This problem is presented often in connection with applications for mortgage insurance or guarantees on housing.

${ }^{2}$ But see discussion in text supra at note 34 . Also, certain programs such as state highway construction programs to which the federal government contributes on a $60-40$ basis are not subject to the Davis-Bacon standards but are covered by Executive Order IIII4.

${ }^{43} 4$ C.F.R. $\$ 60-\mathrm{X} .2(\mathrm{i})$. This does not extend to such "force account" work done by a state or local government agency with its permanent work force.

« Exec. Order No. 10925, \$303, 26 Fed. Reg. 1977 (I96I); Exec. Order. No. $1 \times 114, \S 104,28$ Fed. Reg. 6485 (1963). The Executive Vice Chairman is authorized to withdraw the class excmptions for specific contracts or groups of contracts when in his judgment such action is necessary to achicve the purposes of the orders. However, such withdrawal shall not apply to contracts entered into prior to the withdrawal. 4 I C.F.R. $\$ 60-1.4$ (d) (rg64). 
amounts. ${ }^{45}$ Both are intended to focus the program on those contracts which will have the largest impact on our work force.

Included in the first category of exemptions are contracts to be performed outside the United States "where no recruitment of workers within the United States is involved," 46 and contracts for the sale of government real and personal property "where no appreciable amount of work is involved." 47

The minimum dollar amount of contracts covered except in the case of bills of lading is $\$$ Io,000. ${ }^{48}$ For this purpose, the dollar amount of any federally-assisted construction contract is determined by the amount of the contract itself and not by the amount of federal assistance involved. ${ }^{49}$ A higher dollar exemption- $\$ 100,000$ -is provided for "standard commercial supplies and raw materials." exemption is granted in part because of recognition that such "off the shelf items" often will be produced without any knowledge of whether the ultimate purchaser will be the government or a private party. ${ }^{51}$

Contracts for an indefinite quantity, such as contracts to supply fuel or food as necessary, may also be exempted under the dollar minimum established for coverage. ${ }^{52}$ When the contract is not to extend more than one year, the exemption applies if the contracting agency determines that the amounts to be ordered cannot reasonably be expected to exceed the appropriate dollar minimum. When the contract will extend more than one year, the exemption applies only for any year in which the contracting agency reasonably expects that the dollar minimum will not be met and only if it has not been determined for a prior year that the contract is covered. ${ }^{53}$

${ }^{\triangle D}$ In addition, the Committee has authorized the Executive Vice Chairman with the approval of the Vice Chairman to exempt specific contracts "when he deems that special circumstances so require." $4 \mathrm{I}$ C.F.R. $\$ 60-1.4(\mathrm{~b})(\mathrm{I})$. Where it is "impracticable" to act upon individual requests or where it will "contribute to convenience in the administration of the Orders," groups or categories of contracts of the same type may be exempted. Ibid.

10 II C.F.R. $\$ 60-r .4(a)(3)$ ( 1963$)$. Puerto Rico, the Panama Canal Zone, and the possessions of the United States are included in the definition of the "United States." 40 C.F.R. $\$ 60-I .2(4)$ (Ig64).

${ }^{17} 4$ I C.F.R. $\$ 60-$ I.4(a) (4) (I964).

As 4 I C.F.R. $\$ 60-1.4(a)(I)$ (I964). Under section 60-I.3(b)(4) of the Committee Regulations issued July 22, 196r, bills of lading were not required to include the equal opportunity clauses (3)-(7) concerning compliance, reporting, sanctions or extension of the obligations to subcontractors. This partial exemption is not contained in the Committee Regulations as amended September 7, 1963. Bills of lading may include the equal opportunity clause by reference. 4 I C.F.R. $\S 60-x .3$ (a) (1964).

${ }_{40}^{4}$ I C.F.R. $\$ 60-1.4(a)(\mathrm{r})(\mathrm{rg} 64)$.

${ }^{50} 4$ I C.F.R. $\$ 60-1.4(a)(2)$ ( 1964$)$. "Standard Commercial Supplies" are defined as meaning an article:

"(I) which in the normal course of business is customarily maintained in stock by the manufacturer or any dealer, distributor, or other commercial dealer for the marketing of such article; or

"(2) which is manufactured and sold by two or more persons for general commercial or industrial use or which is identical in every material respect with an article so manufactured and sold."

$4 \mathrm{I}$ C.F.R. $\$ 60-1.2(\mathrm{u})(1964)$. The difficulties of determining whether certain articles are covered by this exemption are discussed in Taylor, supra note 30 , at ro8.

${ }^{5 x}$ Speck, supra note $\mathrm{r}_{3}$, at 253 .

${ }^{5} 4$ I C.F.R. $\S 60-1.4(a)(s)(1964)$.

${ }^{6}$ lbid. 


\section{Subcontracts}

Both Executive Orders I0925 and riri4 direct contractors to include the equal employment opportunity clauses in all nonexempt subcontracts, in order to extend the obligations and protections of the orders to those who contribute to the performance of the government or federally-assisted construction contract. ${ }^{54}$

Subcontractors may be exempt from coverage for one of four reasons:

(I) Their prime contractor is exempt.

(2) One of the exemptions or limitations available to prime contractors applies to the sub, although it did not apply to the prime, e.g., the subcontract is for less than $\$ 10,000$.

(3) The subcontract does not call for work at a construction site ${ }^{65}$ and is below the "second tier," i.e., neither the prime contractor nor a direct subcontractor of the prime is a party to the subcontract. . $^{56}$

(4) A "material part" of the supplies or services covered by the subcontract is not being obtained for use ${ }^{68}$ in the performance of the government contract or federally-assisted construction contract. ${ }^{59}$

\section{D. "Plans for Progress" Contractors}

As of February I, I964, I4I corporations employing approximately seven million workers had signed "Plans for Progress" with the federal government under which they pledge to promote equality of employment opportunity voluntarily-without regard to, or even mention of, the extent of their government contract obligations,

${ }^{61}$ Exec. Order No. 10925, $\$ 30 \mathrm{I}(7), 26$ Fed. Reg. 1977 (1961); Exec. Order No. III $4, \$$ 101, 28 Fed. Reg. $6485(1963)$.

EE ". 'Site of construction' means the physical location of any building, highway or other change or improvement to real property which is undergoing construction, rehabilitation, alteration, conversion, extension, demolition, or repair and any temporary location or facility established by a contractor or sub. contractor specifically to meet the demands of his contract or subcontract." ${ }_{41}$ C.F.R. $\$ 60-1.2(w)$ ( $\left.x g_{4}\right)$.

to 4 I C.F.R. $\$ 60-I .3(c)(1964)$. As Hobart Taylor explained, "This limitation recognizes the fact that in a complex industrial society such as ours the production of a single item may casily involve Io or 15 tiers of producers and that it would be impracticable to attempt to administer the Order through so many tiers of producers, many of whom would have little, if any, relationship with the Government." Taylor, stspra note 30 , at Io6. Under the executive orders preceding rog25 and $111 \times 4$ it was apparently understood that subcontracts below the first tier were not to be covered. See Van Clcve, supra note 9, at 595. This same position might have been taken under Executive Order rog25 as originally issued because the equal opportunity clauses called specifically for inclusion of six of the clauses in subcontracts but not the clause calling for subcontractors to be bound. See Birnbaum, supra note 13, at 23 n.25. This possibility was removed by amendments to the equal opportunity clause in section 201 of Exccutive Order IIII4. The contracting agency or the Executive Vice Chairman may by special order require the clause to be inserted in contracts below the second tier. 4 I C.F.R. $\$ 60-$ I.3 (c) (1964).

67 "The concept of materiality has been used in order to cover the situation where the contractor habitually purchases large quantities of raw materials for stock and then uses them generally in all of his production, including that which is for general non-government consumption . . . A Although the phrase 'material part' is not susceptible of precise definition, it is nevertheless a term used frequently in the law and has come to have a meaning that lawyers should understand." Taylor, stupra note 30, at I07.

is "Use" does not necessarily mean physical incorporation in the government contract or work directly on the government contract, e.g., a subcontract for tools to perform a government contract would be covered by this definition.

${ }^{59} 4$ I C.F.R. $\$ 60-1.2(k)(1964)$. 
if any, to take such action. These contractors are not exempt from Executive Orders I0925 and IIII4 by virtue of having signed a Plan for Progress. ${ }^{60}$

Plans for Progress companies who are nonexempt government contractors are subject to normal compliance review by contracting agencies. In the past, Plan companies, whether government contractors or not, have filed reports on all their plants or establishments on a regional basis, ${ }^{61}$ while government contractors who were not Plan signatories have reported on an individual plant basis but only for those plants engaged in government contract work. Now the two reports have been brought in line with each other and will call generally for plant-by-plant reporting of all facilities of the reporting employer. ${ }^{62}$

The Plans for Progress program reflects the desire of both government and industry to seek a cooperative path to the same objectives set out in the equal opportunity clause-objectives which can be more fully and satisfactorily obtained by cooperation than by compulsion, if the cooperation is meaningful and productive, as it has been in this program. ${ }^{63}$

Mr. Theodore Kheel, a distinguished labor relations arbitrator employed by the President's Committee in 1962 as a consultant, saw the synthesis of these two aspects of the equal employment opportunity program in this way: "Enforcement and persuasion are not separate and distinct, nor incompatible, but related parts of the same program. They are opposite sides of the same coin. Both are necessary and indispensable each to the other."

\section{Obligations of Contractors}

The heart of the federal equal employment opportunity program is in the obligations government contractors and federally-assisted construction contractors assume to provide equal employment opportunity. These obligations are set forth in the

00 "I . . . find, that it has been and will continue to be made clear to all participants in Plans for Progress that the execution of a Plan in no way relieves them of their responsibilities under the Executive Order." Report of Theodore W. Kheel to Vice President Lyndon B. Johnson, Aug. 22, 1962, p. 8.

${ }^{11}$ Section 318 of Executive Order 10925 authorizes the President's Committee to exempt from the reporting requirements any company awarded a "Certificate of Merit" by the Committee. No Certificates have yet been awarded and in its revision of the Regulations effective Sept. 7, 1963, the Committee deleted this reporting exemption for certificate holders.

as Consolidated reports may be filed for manufacturing plants with less than 50 employees and for sales and service offices.

${ }^{03}$ A Plans for Progress Advisory Council has been formed of 19 high-ranking officials of member companies with a staff of 5 junior executives-also from member companies-the latter on' a year's leave of absence. The Advisory Council has organized itself into committee to bring additional companies into the program, to collect and disseminate information about progress and problems encountered and to promote better approaches in education, employment and community relations in connection with equalizing employment opportunity. Each Plan company in turn is expected to develop and implement a program for carrying out its Plan. One of the functions the Advisory Council and staff perform is to act as a clearing house of ideas and means for such programs. Thus far the results of these Plans have been encouraging. The latest combined progress report of the $9 I$ companies that joined the program before January 17,1963 indicates that the proportions of nonwhites employed increased significantly in every occupational category except the lowest paying where they remained about the same.

${ }^{\circ}$ Kheel, supra note 60 , at 6 . 
seven clauses which are to be inserted in all nonexempt contracts. ${ }^{05}$ They go beyond a simple pledge of nondiscrimination and an agreement to post notices of that pledge. In addition, contractors commit themselves to take "affirmative action" to ensure that applicants are employed, and that employees are treated during employment, without regard to their race, creed, color, or national origin. ${ }^{00}$ They also agree to state in all advertisements for employees that all applicants will be considered without discrimination based on race, religion, or national origin; ${ }^{07}$ to report information on their employment practices and to permit access to books and records for purposes of determining compliance; ${ }^{08}$ to comply with the rules, regulations, and relevant orders of the President's Committee; ${ }^{80}$ to obtain contractual pledges of equal employment opportunity from their subcontractors identical to that which they have signed, and to cooperate in securing compliance of such subcontractors if required to do so; ${ }^{70}$ and to notify any labor unions with which they deal of their (the contractors') obligations as equal opportunity employers. ${ }^{71}$

These obligations extend to all of the contractor's operations during the performance of a covered contract and not just to those parts of his operations engaged in performance of such a contract. This intent was made clear in the amendments to the equal opportunity clause contained in section $20 x$ of the Executive Order $\operatorname{IrII}_{4}^{72}$ and in section 202 of that order which authorizes exemption of facilities not involved

${ }^{65}$ Exec. Order No. 10925, 301, 26 Fed. Reg. 1977 (1961); made applicable to federally-assisted construction contracts by Exec. Order No. IIII4, $\$$ IoI, 28 Fed. Reg. 6485 (1963).

${ }^{60}$ Exec. Order No. rog25, $\$ 301$ (I), 26 Fed. Reg. 1977 (I961).

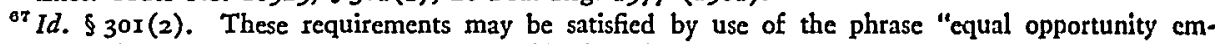
ployer" in advertisements. 4I C.F.R. $\$ 60-1.60$ (d) (I964).

${ }^{68}$ Exec. Order No. rog25, supra note 66, $\$ 301$ (5). Contractors are obligated to make "timely, complete and accurate compliance reports in accordance with, and to the extent required by, the instructions attached to the official compliance report forms." 4 I C.F.R. $\$ 60-1.6 x$ (x964). Failure to file such reports is specifically declared by the Committee Regulations to constitute noncompliance. 4I C.F.R. $\$ 60-1.6(a)(4)$ $(1964)$. Essentially, prime contractors or first tier subcontractors subject to the executive order who have contracts, subcontracts or purchase orders for $\$ 50,000$ or more (or $\$ 100,000$ or more if for standard commercial supplies or raw materials) and who also have 50 or more employees are required to file reports on Standard Form 40. A separate form is provided for government construction contractors. (Form 4I.) This latter form is now being revised to apply to federally assisted construction contractors. As mentioned earlier, Plans for Progress companies file reports on a form similar to Form 40 . Access to books, records and accounts "pertinent to compliance" is to be provided during "normal business hours." qI C.F.R. $\$ 60-1.6 \mathrm{I}\left(\mathrm{I}_{6} 6_{4}\right)$. Information obtained from inspection and from compliance reports is to be used "only in connection wtih the administration of the Orders or in furtherance of their purposes." 4r C.F.R. $\$ \$ 60-\mathrm{r} .8$ and 60-r.6r (rg64).

${ }^{60}$ Exec. Order No. I0925, $\$ 301(4)$. "Rules, regulations and relevant orders" . . mean rules, regulations and relevant orders ... in effect at the time the particular contract subject to the orders was entered into. $4 \mathrm{I}$ C.F.R. $\$ 60-\mathrm{I.2}(\mathrm{s})(\mathrm{Ig} 64)$.

${ }^{70}$ Exec. Order No. 10925, $\$ 301(7)$.

${ }^{71}$ Id. $\S 30 \mathrm{O}(3)$.

${ }^{22}$ The equal opportunity clause as contained in section 301 of Executive Order rog25 began: "In connection with the performance of work under this contract...." This was changed in scction 201 of Executive Order IXII4 to read: "During the performance of work under this contract." The intention was to make clear that while the obligations extend only until contract performance is completed, they are not limited during that time to operations connected with such performance. See Birnbaum, sipra note 13, at 25 n.32. 
in performance of the contract and which asserts coverage over all such facilities not exempted. ${ }^{73}$

The obligations to eliminate and avoid discrimination in all aspects of employment also extend to all parts of covered establishments. It was suggested that this might not be the result under Executive Order 10557 which preceded 10925, because the aspects of employment specified therein related only to "conditions of employment such as hiring, firing, training, and promotion" and therefore matters of "environment," e.g., plant cafeterias and rest rooms, could be considered not covered. $^{74}$ The equal opportunity clause in Executive Order I0925 has not been given such a limited interpretation by those administering it. Furthermore, as suggested by another commentator, segregated treatment during employment is not consistent with the obligations to treat employees without regard to race, creed, color, or national origin. ${ }^{75}$

Of all the obligations Executive Order I0925 places on a contractor none has provoked more comments and questions than the obligation to take "affirmative action" to ensure against discrimination during employment. While the committee has not defined this term in its regulations, ${ }^{76}$ there appear to be two essential elements in this concept. First, contractors must recognize that their commitment to provide equal opportunity is not self-executing. They must ensure that those who act for them in employment matters know that this commitment is to be carried out and establish procedures for doing so. They must also review the performance of their programs and make adjustments where necessary to see that their pledges become practices.

Secondly, contractors have an obligation to demonstrate their willingness to employ without regard to race, creed, color, or national origin. President Kennedy made clear last summer that this does not mean hiring by quotas. ${ }^{77}$ President Johnson has also repeatedly emphasized that employers need not and should not hire a less qualified worker in preference to a more qualified man simply because the former is a member of a minority group.

\footnotetext{
73 The Committee has authorized the Executive Vice Chairman, with the approval of the Vice Chairman, to exempt facilities "which he feels to be in all respects separate and distinct from the activities of the contractor and subcontractor related to the performance of the contract or subcontract, provided that he also finds that such an exemption will not interfere with or impede the effectuation of the Orders." $4 \mathrm{I}$ C.F.R. $\$ 60-1.4$ (b) (2) (Ig64).

76 Van Cleve, supra note 9, at 597 .

${ }^{75}$ See Speck, supra note 13 , at 258 .

${ }^{70}$ The Defense Department has recently supplied a definition and 25 examples for the guidance of its contractors. Daily Labor Report, A-9 to A-12, Jan. 29, 1964. The definition provided is as follows: "Affirmative Action means positive or firm or aggressive action as opposed to negative or infirm or passive action. Affirmative action encompasses the steps necessary to insure that a contractor puts into practice his stated policies of equal employment opportunities without regard to race, color, creed or national origin." As Secretary Wirtz has said, "it means that the program is written and administered not as a STOP sign but as a GO signal." Testimony of Secretary Wirtz before the Subcommittee on Employment and Manpower of the Senate Committee on Labor and Public Welfare on Aug. 2, 1963.

${ }^{77}$ Presidential news conference of Aug. 20, $\mathrm{Ig}_{3}$ as reported in the N.Y. Times, Aug. 21, r963, p. 14, question $\mathrm{I} x$.
} 
However, before the point of hiring, passive nondiscrimination is not enough. The clearest example of this is in recruitment. Where an employer has traditionally failed to employ any minority group members and is in an industry and an area where qualified minority group workers can be expected to be available, he will be expected to undertake recruitment efforts for vacancies to dispel any misimpression that he is biased and to insure that he will have a representative group of applicants from which to select new employees.

Such positive recruitment helps to overcome one of the effects of past discrimination-doubt. It is not a sufficient answer to another effect of such discriminationdisadvantage. Treating equally those disadvantaged by past denials of education and incentives will not produce equal employment opportunity in any meaningful sense. As Secretary Wirtz has said:

... as strongly as I oppose the idea of quotas, as strongly as I would insist that there could be only one standard for hiring, and that is qualification, as strongly would I insist that if we mean business ... we recognize the need for making up for the difference in preparation which has resulted from a century of discrimination. ${ }^{78}$

What is needed is an awareness that skill and ambition are results as well as causes of opportunity and that special institutional and on-the-job training programs are appropriate to train the disadvantaged so that they may compete fairly on the basis of individual merit. For this reason contractors should indicate a willingness to cooperate in such programs and to accept referrals of those adequately trained in skills which they need. ${ }^{79}$

Next to "affirmative action" the two aspects of the contractor's obligations which produce the greatest interest-and concern-are the contractor's responsibility for the practices of his subcontractors and for the arrangements he has agreed to with labor unions.

Neither the executive orders nor the rules and regulations of the President's Committee require contractors to police their subcontractors or to guarantee their compliance. What is required is that nonexempt contractors and subcontractors: (I) insert the equal opportunity clause in nonexempt subcontracts, ${ }^{80}$ (2) require nonexempt subcontractors to file compliance reports in accordance with the instructions on the report forms, ${ }^{81}$ and (3) take such action to enforce compliance by the subcontractor as the contracting agency may direct. ${ }^{82}$ Of course, contractors are also expected not to award subcontracts to any contractor debarred or otherwise publicly declared ineligible because of discriminatory employment practices.

In addition, contractors should understand that they have a responsibility at

${ }^{78}$ Remarks of Secretary Wirtz to Plans for Progress Dinner, Washington, D.C., Jan. x6, x964.

${ }^{79}$ See Speck, supra note 13 , at 258 .

${ }^{80}{ }_{4}$ I C.F.R. $\S 60-\mathrm{r} .3$ (c) $(1964)$.

${ }^{81}$ Exec. Order No. ro925, $\$ 302,26$ Fed. Reg. I977 (rg6r); 41 C.F.R. $\$ 60-1.6(a)$ (1964). "AAdministering agency' means any ... agency .... which administers a program involving federally-assisted construction contracts." 4 I C.F.R. $\$ 60-\mathrm{I} .2$ (p) (1964).

${ }^{82}$ Exec. Order No. 10925, \$301(7), 26 Fed. Reg. 1977 (1961). 
least to report and to seek changes in discriminatory employment practices of subcontractors which come to their attention in the normal course of business. However, in most cases, questions of compliance have been raised first by the contracting agency as a result of a complaint or information obtained from compliance report forms. In such situations, both the agency and the contractor generally prefer to discuss the matter jointly with the subcontractor. Such discussions have been found to be quite effective in producing desired changes. The final section of this paper will discuss the possible application of sanctions to those few subcontractors who refuse to comply with their equal employment opportunity obligations.

The responsibility of contractors for practices agreed to with labor unions is a matter of particular concern in the construction industry where unions often exercise substantial power in referral arrangements and apprentice programs. However, problems also arise at times in connection with the maintenance of segregated bargaining units, job categories, or lines of seniority which have been formalized in collective bargaining agreements.

Several points should be made at the outset of any discussion of this matter:

I. There is no exemption from coverage-express or implied-for those apprenticeship programs, referral agreements, and other arrangements relating to employment which are contained in collective bargaining agreements.

2. There are some situations where individual local unions may resist bona fide efforts of contractors to comply with their equal employment opportunity obligations. There are fewer situations in which a contractor is under a legal disability to comply with his equal employment opportunity obligations unless a union approves.

3. The contractor's obligation to provide equal employment opportunity does not stop with seeking a pledge of cooperation, if asked to do so, from the union representing his employees and reporting any refusal on the union's part to sign such a pledge and the efforts he has undertaken to secure it. ${ }^{83}$

4. By holding contractors to their commitments the government may cause them to insist on necessary changes and may provide a basis for changes which local union officials can justify to their membership.

5. The government cannot permit itself to be caught in the middle between contractors who claim that they are not able to fulfill their commitments to provide equal employment opportunity and unions who point out that they have not obligated themselves to provide such opportunity. ${ }^{84}$

${ }^{83}$ Those specific obligations are contained in Exec. Order No. $10925, \S 302$ (d), and section 60-r.6(b) (2) of the Committee's Regulations.

${ }^{84}$ See Todd v. Joint Apprenticeship Committee, supra note 13 , where a federal contracting agency and the Bureau of Apprenticeship and Training were found to have aided and participated in discrimination in apprenticeship on a federal project and in a federally-registered apprenticeship program. See also discussion of constitutional obligations on the government to avoid participation in discrimination even in procurcment, in Speck, supra note 13. 
6. Direct prohibitions are needed against discrimination in employment by unions as well as employers.

Beyond this it should be recognized that, while some local unions may not cooperate in efforts to promote equal employment opportunity, the labor movement as a whole is and has been strongly committed to equality of opportunity and to civil rights generally. Many unions on their own initiative have sought and obtained nondiscrimination clauses in their collective bargaining agreements. Strictly as a voluntary matter, the AFL-CIO and II6 of its international union affiliates signed Programs for Fair Practices with then Vice President Johnson under which they agreed to take affirmative action to promote equal opportunity in all aspects of employment and to seek management agreement to changes where necessary. Most of the international unions which signed such programs subsequently appointed international representatives who work with the President's Committee on matters involving their local unions.

It is important to realize that the AFL-CIO and its international unions are seldom in a position to "tell" a local union what it must do on a question of equal employment opportunity. Local unions are proud of their "autonomy" and are concerned about the job security of their members. Faced with such attitudes, some local union officials, lacking tenure and facing re-election, may be reluctant to support the kind of affirmative action that will promote opportunities for so-called "outsiders."

Moreover, union action to promote equal employment opportunity may be used against them by some employers in the South who seek to persuade their employees to remain unorganized..$^{85}$ The National Labor Relations Board has recently indicated its awareness of this problem by throwing out an election result against a union where the employer sought to arouse racial prejudice by "irrelevant, inflammatory appeals." ${ }^{386}$ However, to the extent that the Board finds that certified bargaining agents have a duty to represent all employees without discrimination, or determines that discrimination in representation is an unfair labor practice or a defense to a charge of refusal to bargain, this problem of organized labor in the South may be intensified. At the same time, such determinations of the Board may be appropriate under the statute and, in some cases, even compelled by the Constitution. ${ }^{87}$

Despite these difficulties, international unions of the AFL-CIO have acted to reduce the number of segregated locals, to support Fair Employment Practices legislation prohibiting discrimination in employment and union membership, and

\footnotetext{
${ }^{85}$ See Sovern, The National Labor Relations Act and Racial Discrimination, 62 CouvM. L. Rev. 563, 6r4-30 ( $\mathrm{rg} 62)$.

${ }^{86}$ Sewell Mfg. Co., 138 N.L.R.B. No. 12 (1962) (distribution of a photo of union president dancing with a Negro woman). On the other hand, an employer statement on "matters of racial interest temperate in tone, germane, and correct factually" will be permitted. See Morrison Sign Co., Inc., I38 N.L.R.B. No. II (I962); Sharnay Hosiery Mills, Inc., 120 N.L.R.B. 750 (I958) and Sovern, supra note 85, at 626, 627.

${ }^{87}$ See generally, Sovern, supra note 85 ; Weiss, Federal Remedies for Racial Discrimination by Labor Unions, 50 GEO. L.J. 457 (1962).
} 
to foster support for equal opportunity in all aspects of community life. ${ }^{88}$ There are also some signs of progress in developing procedures to provide equal apprenticeship opportunity. ${ }^{80}$

Where local unions do not cooperate in providing equal employment opportunity, the contracting agency must insure that the policy of the federal government is not sacrificed to preserve labor-management "good-will." ${ }^{20}$ The agency's general position must be that while contractors may delegate authority over some aspects of their employment practices or otherwise limit their own freedom, they will be considered responsible for such practices as far as they affect equal employment opportunity. ${ }^{91}$ At the same time, the agency and the President's Committee, recognizing the complexity of the problem, must assist in trying to secure union cooperation. ${ }^{92}$ The possibilities for persuasion, in conjunction with the AFL-CIO and international union representatives, have been mentioned above. Such efforts have been successful not only in eliminating segregated locals, ${ }^{93}$ but also in merging discriminatory lines of seniority in a Birmingham steel company ${ }^{94}$ and in producing some significant break-throughs in certain local building trades. ${ }^{95}$ Beyond conciliation, some other actions are available to the Committee where unions do not cooperate in providing equal employment opportunity. These will be discussed in the following section, which deals with enforcement procedures.

${ }^{88}$ The AFL-CIO established a special six-man Committee on Civil Rights in the summer of 1963 under the chairmanship of President George Meany and assigned two staff men to promote the establishment of biracial committees in 40 cities throughout the country.

${ }^{80}$ The Construction Industry Joint Conference, composed of building trades unions and national contractors associations, has issued a recommended apprentice selection system designed to foster selection on the basis of qualifications alone without regard to race, creed, color or national origin. See N.Y. Times, Oct. 20,1963, p. I. These recommended standards are somewhat less detailed than the standards issued by the Secretary of Labor to achieve the same objective. 29 Fed. Reg. II313 (1963). Apprenticeship programs which are federally registered will be expected to operate in a manner consistent with the Secretary's standards.

${ }^{\circ}$ Thus far there has been no support for the right of a minority group member to maintain an action to obtain the benefits of the government contract. Todd v. Joint Apprenticeship Committee, supra note I3; Farmer v. Philadelphia Electric Co., 2I5 F. Supp. 729 (E.D. Pa. I963); see also, Speck, supra note I3, at 259.

${ }^{91}$ See General Services Order PBS 2800.15 I7, figure 2, dated April 22, I963, stating that "The inability of any contractor to control completely his source of labor does not relieve him of his contractual responsibilities."

${ }^{03}$ Under $\$ 304$ of Exec. Order No. 10925, the Committee is to ". . . use its best efforts, directly and through contracting agencies, contractors, state and local officials and public and private agencies, and all other available instrumentalities, to cause any labor union, recruiting agency or other representative of workers who is or may be engaged in work under government contracts to cooperate with, and to comply in the implementation of, the purposes of this order." Section 60-1.7 of the Committee's Regulations designates the Executive Vice Chairman to perform such functions.

${ }^{03}$ The Oil, Chemical, and Atomic Workers Union has now eliminated all of its segregated locals. The Tobacco Workers have reduced the number of segregated locals in their international from 25 to 7 .

ot Tennessee Coal and Iron Division of U.S. Steel Co.

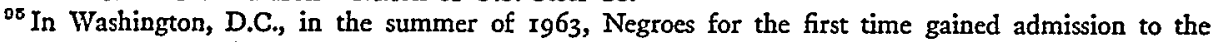
apprentice programs of the Ironworkers, Plumber and Pipefitter locals and substantially increased their participation in the Electricians program. Also, all building trades locals in Washington agreed to accept for membership any journeymen employed by a local contractor. 


\section{Enforcement Procedures}

Theodore Kheel noted in his report to then Vice President Johnson that "Enforcement is necessary if meaningful reduction in employment discrimination is to be achieved." As the same time, he also noted that "Experience also proves that a combination of conciliatory methods, backed by the implicit threat of enforcement, is the most effective approach."

This is the approach called for in the executive order and in the regulations of the President's Committee. A variety of sanctions are available if compliance cannot be obtained by persuasion and mediation. In the words of one authority on government contract law, "Rather than relying solely on education or moral persuasion, those seeking to prevent discrimination are attempting to make legally enforceable a clause that has, until now, been an insignificant part of the 'boiler-plate' in government contracts." 98

As Hobart Taylor, former Special Counsel of the Committee and now its Executive Vice Chairman, said shortly after the promulgation of Executive Order rog25: The committee seeks to accomplish its objectives primarily by alerting American business to the needs of the hour and seeking their voluntary cooperation in the successful execution of this task, and in this effort the committee has experienced great success. We do not anticipate the use of any of the sanctions set forth in this order, although we are prepared to use them if we find ourselves compelled to do so.99

Before describing the various sanctions, mention should be made of the orientation of the enforcement effort and the way in which responsibility for enforcement is shared among contracting or administering agencies, the Committee, and applicants for federal assistance.

The basic decision which has been made in enforcement is to seek those situations which offer the greatest possibility for significant changes in employment opportunities. This means that attention is focused on the general employment practices and patterns of contractors and that the enforcement program involves more than the adjudication of individual complaints. ${ }^{100}$

Those complaints which are received are fully investigated and adjusted, of course. ${ }^{101}$ In addition, however, an individual complaint is used as the basis for a general compliance review of the establishment in which the alleged discrimination occurred. Where appropriate, any adjustment of employment practices to be made as a result of a complaint investigation is extended to all employees similarly discriminated against in the establishment. For example, complaints of discrimination in promotional opportunities at the Tennessee Coal and Iron Division of U.S.

${ }^{\circ}$ See Kheel, supra note 60 , at 6,7 , quoting Paul H. Norgren.

${ }^{07}$ Id. at 7 .

${ }^{98}$ See Speck, supra note 13 , at $243,244$.

${ }^{00}$ See Taylor, supra note 30 at 105.

${ }^{100}$ See Birnbaum, supra note 13 , at 21 n.r 8 .

${ }^{101}$ As of January $31,1964,2312$ complaints have been received. 1721 of these cases have been closed; corrective action was found necessary and was taken in 67.6 per cent of the cases. 
Steel in Birmingham became the basis for a general revision of lines of seniority. Many other compliance reviews are initiated without a complaint having been filed. This is done in recognition of the reluctance of many individuals to file complaints and of the importance of finding those areas where the most significant improvements in employment opportunities can be made.

An essential tool in planning such special compliance reviews are the reports contractors file of the composition of their work force. Of course, the fact that few, if any, minority group members are employed in a particular plant, division, type of job, or grade does not establish noncompliance. However, it may indicate a situation worth reviewing.

Apart from complaint-initiated reviews and those stimulated by reports filed, agencies also try to review on a periodic basis all covered establishments not otherwise reviewed. Such reviews focus on those matters not described in the reports filed, such as recruitment and training programs, facilities, and so on.

Primary responsibility for all enforcement activities is placed on the contracting or adminstering agencies by the executive orders and the Committee's regulations. ${ }^{102}$ The agencies develop their own compliance programs, conduct the compliance reviews, handle efforts to obtain compliance through conciliation and, if necessary, hold hearings and recommend the imposition of sanctions. ${ }^{103}$ The committee staff acts as a co-ordinator and interpreter of general policies and designates which agency has the predominant interest in cases of contractors who have dealings with more than one agency. ${ }^{104}$ It also analyzes agency programs and suggests appropriate revisions. The staff also reviews agency decisions on complaints and findings on compliance reviews.

In addition, the Executive Vice Chairman has power to assume jurisdiction over matters before an agency "where he considers it necessary or appropriate to the achievement of the purposes of the Orders." ${ }^{105}$ Also, because the Executive Vice Chairman is specifically charged with responsibility for securing labor union cooperation, ${ }^{108}$ agencies generally look to the committee staff for assistance in matters requiring liaison with unions.

Sections ror and ro3(a) of Executive Order IIIr4 call for those applying for federal grants or other financial assistance for construction to agree to furnish information which the administering agency may request and to assist otherwise in the agency's discharge of its primary responsibility of supervising compliance. The applicants also must agree to refrain from awarding contracts covered by Executive Order IIII4 to those declared ineligible under that order or Executive Order 10925 and to carry out such sanctions against covered contractors and subcontractors as

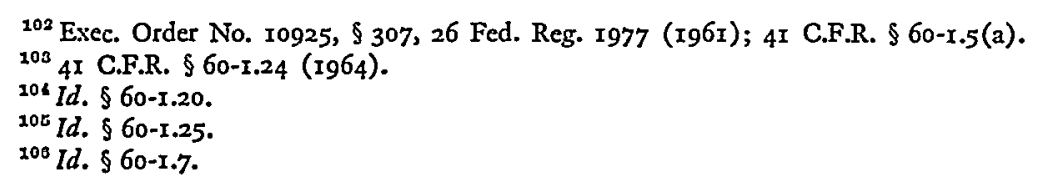


the agency or the committee may impose pursuant to the orders and regulations. ${ }^{107}$

The sanctions available include (I) publication of the names of noncomplying contractors; ${ }^{108}$ (2) public hearings and reports to the President concerning noncooperating unions; ${ }^{109}$ (3) requests to the Department of Justice for enforcement actions in cases of substantial or material violation or threat thereof "including enjoining within the limits of applicable law an organization, individuals or groups" who prevent compliance directly or indirectly; ${ }^{110}$ (4) recommendations to the Department of Justice that criminal proceedings be brought for the furnishing of false information; ${ }^{111}(5)$ termination or suspension in whole or in part of contracts or grants when the contractor or recipient of the grant is not complying with its undertakings to provide equal employment opportunity; ${ }^{112}$ (6) debarment, notice of ineligibility for further government contracts or federally-assisted construction contracts, or refraining from extending further assistance until proof of compliance is provided. ${ }^{113}$

Noncomplying contractors have a right to a hearing in debarment proceedings. ${ }^{114}$ They are also entitled to notice before contract termination or before their case is referred to the Justice Department for enforcement. ${ }^{115}$ In a letter to then Vice President Johnson dated September 26, I96r, Attorney General Robert F. Kennedy concluded that the sanctions provided for in Executive Order 10925 were appropriate and that the safeguards established by the Committee to protect the procedural rights of contractors were adequate. ${ }^{116}$

To date, notices of ineligibility for future contract awards have been issued in the case of eight government contractors. These notices were issued because evidence had been received indicating noncompliance and adequate information had not been provided by the contractor to permit a determination to the contrary. The notices do not constitute a judgment of noncompliance as would be made in a debarment proceeding. However, they have proven to be an effective way of gaining contractor assurances of future compliance.

Possible enforcement action in the case of noncomplying subcontractors is illustrated by one of the cases in which a notice of ineligibility was issued. The company declared ineligible was a subcontractor rather than a prime contractor. Despite the noncompliance of the subcontractor, no action was considered necessary against the prime contractor.

${ }^{107} I d . \S 60-\mathrm{r} .3(\mathrm{~b})$.

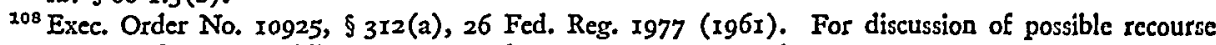
of a contractor for such publication, see Speck, supra note 13, at $26 \mathrm{r}$.

${ }^{109} \mathrm{Id}$. $\S 305$.

${ }^{110} \mathrm{Id}$. $\$ 3 \mathrm{I2}(\mathrm{b})$. The possibilities of obtaining injunctive relief to enforce obligations to provide equal employment opportunity are discussed in Pasley, supra note I3, at 852-53.

${ }^{111} I d . \$ 3 I 2(\mathrm{c})$.

${ }^{112}$ Id. $\$ 3_{312(d)} 301(6)$ as amended. Exec. Order No. IIII4, $\$$ ro3(b)(1), 28 Fed. Reg. 6485 (I963).

${ }^{113}$ Exec. Order 10925, $\$ \S 312(\mathrm{c}), 314,26 \mathrm{Fed}$. Reg. 1977 (196r); Exec. Order 1III4, $\$ 103(\mathrm{~b})(2)$, 28 Fed. Reg. 6485 (1963).

114 Exec. Order 10925, §3то(b), 26 Fed. Reg. 1977 (196r).

${ }^{115} 4$ I C.F.R. $\$ 60-1.28$ (1964).

${ }^{110} \mathrm{See}$ Taylor, supra note 30 at I01-02. 
Should it be considered necessary to require termination of a subcontract in any case, the government will of course stand by to protect its interest if litigation results. Should the prime contractor fail to comply with his obligations to terminate the subcontract in such a case, the Committee might seek to require such termination by referring the case to the Department of Justice for injunctive action. Also, the government might be able to maintain an action directly against the subcontractor as a third party beneficiary of the equal opportunity clause in the subcontract.

However, contract terminations or suspensions do not seem to be sanctions which will often be used. Declaring noncomplying contractors ineligible for future work may be a better method of handling most of these situations. In fact, compliance officers may devote more attention in the future to determining ability to comply in advance of contract award.

Such determinations of ability to comply, analogous to determinations of "financial responsibility," would be particularly appropriate where arrangements with labor unions allegedly interfere with the ability of contractors to fulfill equal opportunity commitments.

\section{ConCLUSION}

Presidential authority and the procurement function have been used in Executive Orders I0925 and IIII4 to promote equal employment opportunity. These orders have helped to make clear that equal opportunity calls for affirmative action to remove doubts and to overcome disadvantages resulting from past discrimination. Significant cooperation has been provided by business and labor and the result has been progress-measured in people as well as in plans. ${ }^{117}$

Equal employment opportunity remains at the junction of two of our major national concerns-civil rights and full employment. We cannot make equal employment opportunity a reality independent of our efforts to assure civil rights to all our people and to provide jobs for all those able and willing to work.

Unless there are adequate job opportunities, other rights lose much of their meaning. At the same time denials of education and use of public accommodations limit our ability to provide equal employment opportunity.

Fair employment cannot be separated from full employment. We cannot achieve full employment as long as a substantial part of our population is not fully participating in our economy. Also, our problem in providing job opportunities for the Negro and other minority groups is only a particularly serious part of the general needs to expand our economy, to combat poverty and to improve education. Programs to meet these general needs are as important to equal employment opportunity as fair employment practices legislation and the continuation of the government contract program by executive order.

If the federal government is to make its full contribution to our national pledge of equal opportunity, it must continue to take action in all of these ways.

${ }^{11 \pi}$ See note 63 supra. 